\title{
HUMIDITY IN ANAESTHESIOLOGY \\ IV: DETERMINATION OF THE ALVEOLAR HUMIDITY AND TEMPERATURE IN THE DOG*
}

\author{
RaYNaLd DÉRY, M.D., F.R.C.P.(C) $\uparrow$
}

IN MAN, as in other air breathers, the membrane for exchange of gases between blood and air is located deep inside the chest, and is divided into microscopic subsections at the ends of many branches of a long narrowing tracheobronchial tree. From the trachea to the alveolar sacs, the number of these dichotomic divisions amounts to $23.1^{1}$ Because of this involuted construction, the alveolar membrane, undoubtedly the most delicate barrier between the atmosphere and the body fluids, seems to be well protected against cold, trauma, and dehydration. However, it has been pointed out that anatomic and physiologic alterations can be induced in the respiratory functional unit either by supersaturated aerosols, ${ }^{2}$ or by desiccation of the inspired atmosphere. ${ }^{3}$

We have previously conducted studies in our laboratory during clinical anaesthesia with the semiclosed system, using the giant soda lime absorber. In this condition, the inhaled gas mixture closely reproduces in the upper airways the climatologic conditions which are known to exist in the normal man breathing through his nose. ${ }^{4,5}$ These results led us to more knowledgeable interplay of the biophysical factors at work to protect the mucous membranes. These factors, heat gain, heat loss, moisture gain, moisture loss, evolve in a very dynamic pattern. A dry inspired gas mixture demands greater evaporation from the mucosa, which cools down owing to the latent heat of vaporization. Eventually, heat and water follow the linear pattern of a parallel increase, and reach a physiological state of saturation at body temperature. This equilibrium occurs just below the carina. In the next expiratory phase, the heat and water lost during the previous inspiration are ideally nullified through dew deposits and water recapture on the mucous membranes. So, after a few respiratory cycles, under given climatologic conditions, the upper airway reaches a new equilibrium, and behaves as a self compensating biophysical system. It thus seems likely that the respiratory system has special characteristics that enable it to cope successfully with various environments, and can develop acute as well as chronic adaptation.

Surprisingly enough, but in agreement with the biophysical principles involved, the exposure of two patients to a completely dehydrated anaesthetic gas mixture, administered through a non-rebreathing valve, yielded almost identical results. This work, under completion, yields strong support to our previous conclusions. ${ }^{6}$

*This work is supported by the Grant No. Ma 2968, provided by the Medical Research Council

This study was presented, in part, at the Wesley Bourne Memorial Lecture, McGill University, Friday, 29 May 1970.

†From the Department of Anaesthesia and Resuscitation, L'Hôtel-Dieu de Québec and Laval University. 
Unfortunately, the caliber of our humidity and temperature sensors prevented us from obtaining heat and moisture readings in the small peripheral bronchi. We were then still deeply concerned with the possibility that, under extreme conditions of hyperventilation with a dry gas, air could eventually reach the alveoli at a temperature and humidity below the physiological normals. Abnormalities at this level, induced either by cold or desiccation, could contribute decisively to functional or structural alterations of the alveolar linings. ${ }^{7}$ This study reports measurements of temperature and relative humidity sampled directly from the alveolar cavity, in the dog.

\section{METHODS}

The present investigation consists of a series of acute experiments performed on a total of 10 mongrel dogs, believed to have been in good physical condition at the time of the experimentation. Each animal, after an overnight fast, was premedicated with $15 \mathrm{mg}$ morphine and $0.4 \mathrm{mg}$ atropine, before light anaesthesia was induced by intravenous administration of thiopentone. After endotracheal intubation, oxygen and nitrous oxide were administered through a non-rebreathing Fink or Ambu valve. In all animals, a pair of cannulae were inserted into the femoral vein and artery respectively to monitor haemodynamics. Oesophageal and rectal temperature probes were connected to a Yellow Springs multichannel Telethermometer. Pulmonary ventilation, obtained with a Bird Mark 7 respirator, was monitored with a Wright Ventilometer. Gas analysis was monitored with the I.L. model 113 polarographic electrodes. Data were fed into a Hewlett-Packard multi-channel preamplifier-recorder.

A right thoracotomy was performed through the bed of the fifth rib, and the lung was exposed. On the surface of one lobe of the lung, a few alveoli were severed with a cautery. This insured instant coagulation of any small blood vessel which might ooze during the following experiment. In fact, we created a superficial and circular aperture, about 3 millimeters in diameter, which initially behaved as a bronchiolo-alveolar fistula.

A huge artificial alveolus, in practice a regular latex prophylactic, was sutured around the fistula. In order to avoid any blood contamination of the sampling cavity, special care was devoted to perform exterior mattress stitches around a rubber ring to which the neck of the prophylactic had previously been fixed with adhesive glue (Figure 1).

Once this was complete, the thermistor (Yellow Springs No. 421-36) and the humidity sampling tube ${ }^{8}$ were introduced into the alveolus. Airtight inlets for these devices were insured by external occlusive ligatures. The alveolus was then seen to inflate with inspiration, and to deflate during expiration. It showed dynamics which mimic those of a real alveolus, except for blood perfusion, which was obviously absent. It received from 3 to $5 \mathrm{cc}$ of each tidal volume. It was indeed with some nostalgia that we closed the thorax over this assembly. The absence of leaks in the system was observed through an underwater thoracic drain. The whole experimental display is illustrated in Figure 2. 


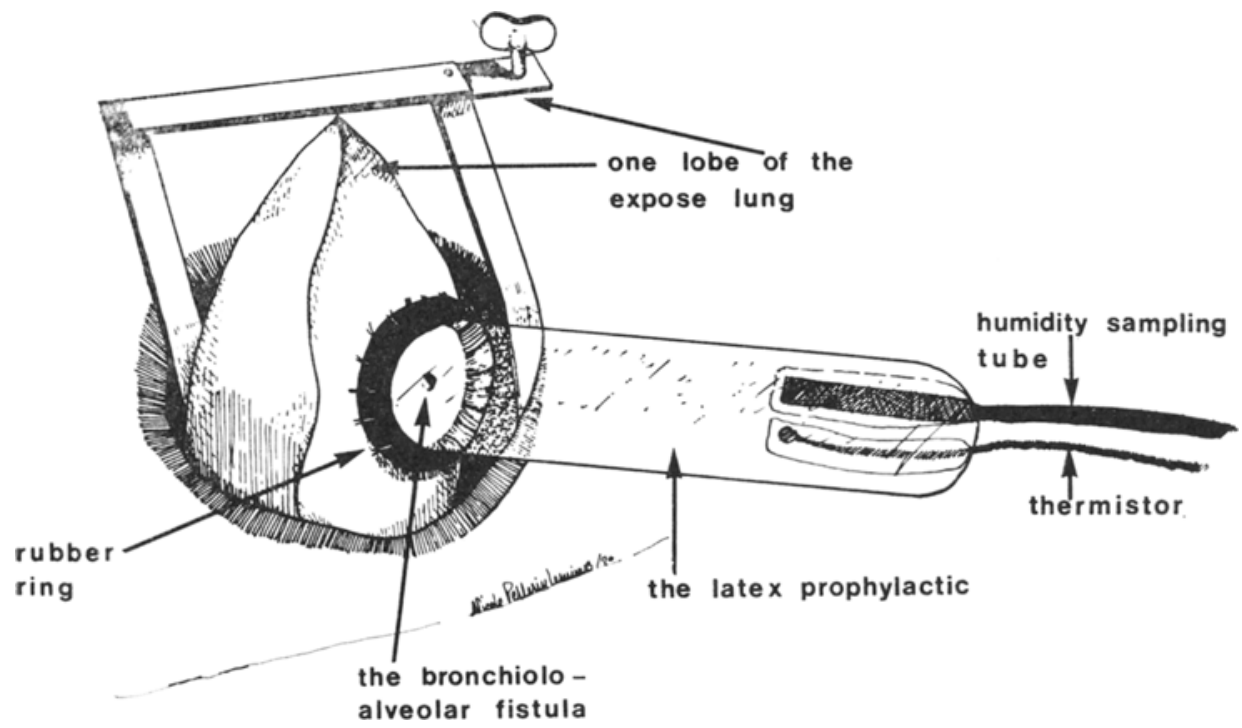

Frgure 1. Outline of the artificial alveolar unit.

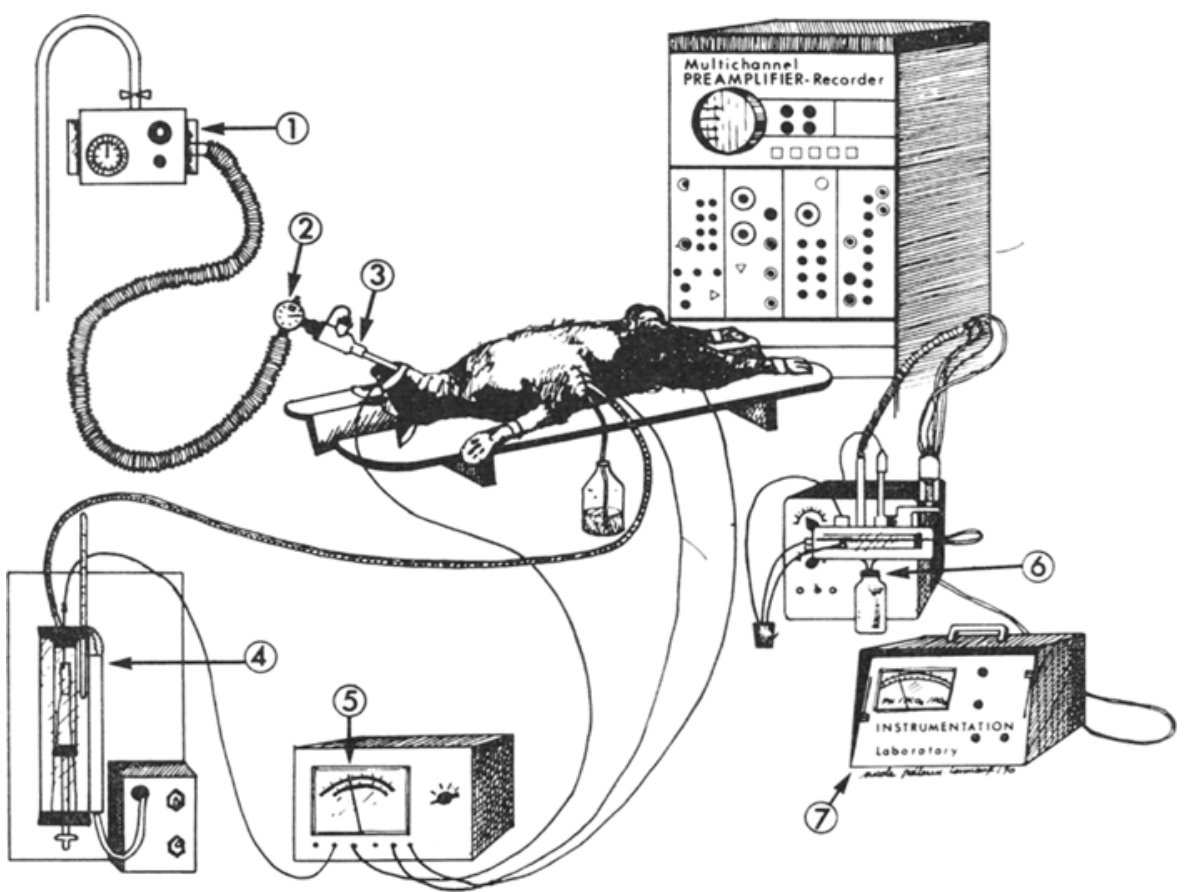

Figure 2. Diagram of the whole assembly for the measurement of relative humidity and temperature in the alveolar cavity. Components of the system include: 1. a Bird Respirator; 2. a Wright Ventilometer; 3. a Fink's valve; 4. a hygrometer; 5. a multichannel Telethermometer; 6. polarographic electrodes for $\mathrm{Po}_{2}$ and $\mathrm{PCO}_{2}$ readings; 7. a IL gas analyzer preamplifier, and a multichannel preamplifier-recorder. 
TABLE I

Measurements of the Alveolar Humidity and Temperature in Ten Dogs, along with Pertinent Data on Pulmonary Ventilation and Rectal TeMperature

\begin{tabular}{|c|c|c|c|c|c|}
\hline $\begin{array}{l}\text { Study group } \\
\text { Dog No. }\end{array}$ & $\begin{array}{l}\text { Time } \\
\text { min }\end{array}$ & $\begin{array}{l}\text { Pulmonary } \\
\text { ventilation } \\
\text { liters } / \mathrm{min}\end{array}$ & $\begin{array}{l}\text { Alveolar } \\
\text { relative } \\
\text { humidity } \\
\text { per cent }\end{array}$ & $\begin{array}{c}\text { Alveolar } \\
\text { temperature } \\
{ }^{\circ} \mathrm{C}\end{array}$ & $\begin{array}{c}\text { Rectal } \\
\text { temperature } \\
{ }^{\circ} \mathrm{C}\end{array}$ \\
\hline 1 & $\begin{array}{r}0 \\
20 \\
40 \\
60\end{array}$ & $\begin{array}{r}5.9 \\
9.5 \\
15.2 \\
18.4\end{array}$ & $\begin{array}{r}100 \\
100 \\
99 \\
100\end{array}$ & $\begin{array}{l}36.8 \\
36.6 \\
36.4 \\
36.4\end{array}$ & $\begin{array}{l}36.5 \\
36.7 \\
36.8 \\
36.4\end{array}$ \\
\hline 2 & $\begin{array}{r}0 \\
20 \\
40 \\
60\end{array}$ & $\begin{array}{r}5.5 \\
10.2 \\
19.6 \\
32.2\end{array}$ & $\begin{array}{c}99.5 \\
100 \\
99.5 \\
99.9\end{array}$ & $\begin{array}{l}36.5 \\
36.2 \\
36.7 \\
36.5\end{array}$ & $\begin{array}{l}36.5 \\
36.3 \\
36.2 \\
36.6\end{array}$ \\
\hline 3 & $\begin{array}{r}0 \\
20 \\
40 \\
60\end{array}$ & $\begin{array}{r}2.8 \\
5.1 \\
10.4 \\
20.0\end{array}$ & $\begin{array}{c}100 \\
100 \\
99.9 \\
99.8\end{array}$ & $\begin{array}{l}36.7 \\
37.0 \\
36.5 \\
36.3\end{array}$ & $\begin{array}{l}36.6 \\
36.6 \\
36.3 \\
36.2\end{array}$ \\
\hline 4 & $\begin{array}{r}0 \\
20 \\
40 \\
60\end{array}$ & $\begin{array}{r}4.8 \\
10.0 \\
15.0 \\
20.2\end{array}$ & $\begin{array}{l}100 \\
100 \\
100 \\
100\end{array}$ & $\begin{array}{l}36.7 \\
36.4 \\
36.0 \\
35.5\end{array}$ & $\begin{array}{l}36.5 \\
36.3 \\
36.2 \\
35.8\end{array}$ \\
\hline 5 & $\begin{array}{r}0 \\
20 \\
40 \\
60 \\
80\end{array}$ & $\begin{array}{r}3.0 \\
5.1 \\
10.0 \\
20.0 \\
30.0\end{array}$ & $\begin{array}{l}100 \\
100 \\
100 \\
100 \\
100\end{array}$ & $\begin{array}{l}37.0 \\
36.5 \\
36.1 \\
35.6 \\
35.0\end{array}$ & $\begin{array}{l}37.2 \\
36.3 \\
36.2 \\
35.5 \\
35.0\end{array}$ \\
\hline 6 & $\begin{array}{r}0 \\
20 \\
40 \\
60 \\
80\end{array}$ & $\begin{array}{r}5.6 \\
10.0 \\
16.0 \\
21.0 \\
26.0\end{array}$ & $\begin{array}{r}97 \\
100 \\
100 \\
100 \\
100\end{array}$ & $\begin{array}{l}39.0 \\
39.0 \\
38.7 \\
38.4 \\
38.3\end{array}$ & $\begin{array}{l}38.2 \\
38.2 \\
38.5 \\
38.5 \\
38.3\end{array}$ \\
\hline 7 & $\begin{array}{r}0 \\
20 \\
40 \\
60 \\
80\end{array}$ & $\begin{array}{r}5.0 \\
10.0 \\
15.0 \\
20.0 \\
30.0\end{array}$ & $\begin{array}{l}100 \\
100 \\
100 \\
100 \\
100\end{array}$ & $\begin{array}{l}35.9 \\
36.5 \\
35.0 \\
35.4 \\
34.8\end{array}$ & $\begin{array}{l}35.4 \\
35.2 \\
35.5 \\
35.0 \\
34.8\end{array}$ \\
\hline 8 & $\begin{array}{r}0 \\
20 \\
40 \\
60\end{array}$ & $\begin{array}{r}5.0 \\
10.0 \\
15.0 \\
20.0\end{array}$ & $\begin{array}{r}97 \\
99 \\
100 \\
100\end{array}$ & $\begin{array}{l}36.6 \\
36.6 \\
36.4 \\
36.0\end{array}$ & $\begin{array}{l}36.6 \\
36.0 \\
35.9 \\
35.0\end{array}$ \\
\hline 9 & $\begin{array}{r}0 \\
20 \\
40 \\
60 \\
80\end{array}$ & $\begin{array}{r}5.0 \\
10.0 \\
15.0 \\
20.0 \\
29.0\end{array}$ & $\begin{array}{l}100 \\
100 \\
100 \\
100 \\
100\end{array}$ & $\begin{array}{l}36.0 \\
36.0 \\
35.5 \\
35.0 \\
35.0\end{array}$ & $\begin{array}{l}36.0 \\
36.0 \\
35.8 \\
35.2 \\
34.5\end{array}$ \\
\hline 10 & $\begin{array}{r}0 \\
20 \\
40 \\
60 \\
80\end{array}$ & $\begin{array}{r}5.0 \\
10.0 \\
15.0 \\
20.0 \\
25.0\end{array}$ & $\begin{array}{l}100 \\
100 \\
100 \\
100 \\
100\end{array}$ & $\begin{array}{l}37.5 \\
37.2 \\
37.0 \\
36.8 \\
36.0\end{array}$ & $\begin{array}{l}37.5 \\
37.1 \\
37.0 \\
36.8 \\
36.0\end{array}$ \\
\hline Mean & & & 99.8 & 36.5 & 35.6 \\
\hline \multicolumn{3}{|c|}{$\begin{array}{l}\text { Standard deviation } \\
\text { of the mean }\end{array}$} & 1.73 & 1.05 & 0.5 \\
\hline
\end{tabular}


For an internal check of our method, several samples were run a sufficient number of times to obtain an estimated variation. Our margin of error read below $0.2^{\circ} \mathrm{C}$ for temperature, and \pm 1 per cent relative humidity.

Using techniques previously described, ${ }^{5,8}$ temperature and humidity readings were obtained from the sampling alveolus every 20 minutes. Meanwhile, pulmonary rentilation was increased in a stepwise fashion, the minute volume being increased in sequence, until very high limits of ventilation were reached. Our results are illustrated in Table I.

Determinations of the alveolar relative humidity disclosed a monotonous result of 100 per cent (SD 1.73), for any degree of hyperventilation with the dry gas mixture.

Likewise, temperature in the alveolar cavity remained stable at body temperature. However, we noticed, during some experiments in this series, a slight tendency towards a fall in body temperature. The rectal temperature fell about $0.5^{\circ} \mathrm{C}$ in one hour, and $1^{\circ}$ in 2 hours, from which point it stabilized over the next two hours. This fall in temperature could be due in part to the cooling effect of water evaporating in the upper airway. It was probably due to the poikilothermic state induced by anaesthesia.

\section{Discussion}

It is of interest that overwhelming hyperventilation with a dry atmosphere had no effect upon the climatic conditions of the alveolar cavity.

These observations have opened other avenues of investigation. First, they provide a technique for sampling alveolar air. This technique could be standardized to craluate the pharmacology of the peripheral airway. The inflow and outflow of air into the artificial cavity can be easily measured and, therefore, represents an indirect method for evaluating bronchomotor tone.

Then. it was a successful attempt in measuring alveolar gas temperature. As far as the author is aware, knowledge about the temperature of the alveolar cavity has been far from complete. Usually, it has been estimated by various indirect methods, including the passage of temperature sensitive devices far into the pulmonary blood vessels, the oesophagus, and the bronchial tree. ${ }^{9-17}$

Moreover. this study permitted a factual contact with an alveolar component of the anatomical dead space, that is, ventilation in a non perfused alveolus.

Finally, it demonstrated the adequacy, as well as the dimension of the functional capacity of the upper airway as an air conditioning system during anaesthesia.

If we try now to integrate our previous studies dealing with the measurement of humidity and temperature in the upper airway ${ }^{*}$ with the results obtained from the alveolar cavity, we can divide the whole airway into two segments (Figure 3 ) - the upper airway and the lower airway. Dynamic heat and moisture exchanges eventually lead from the upper into the lower to a physiologic equilibrium of 100 per cent relative humidity at body temperature. The transition between these two segments can be delineated by what we call the Isothermic Saturation Boundary, or ISB. This boundary is of importance for anaesthesiologists 


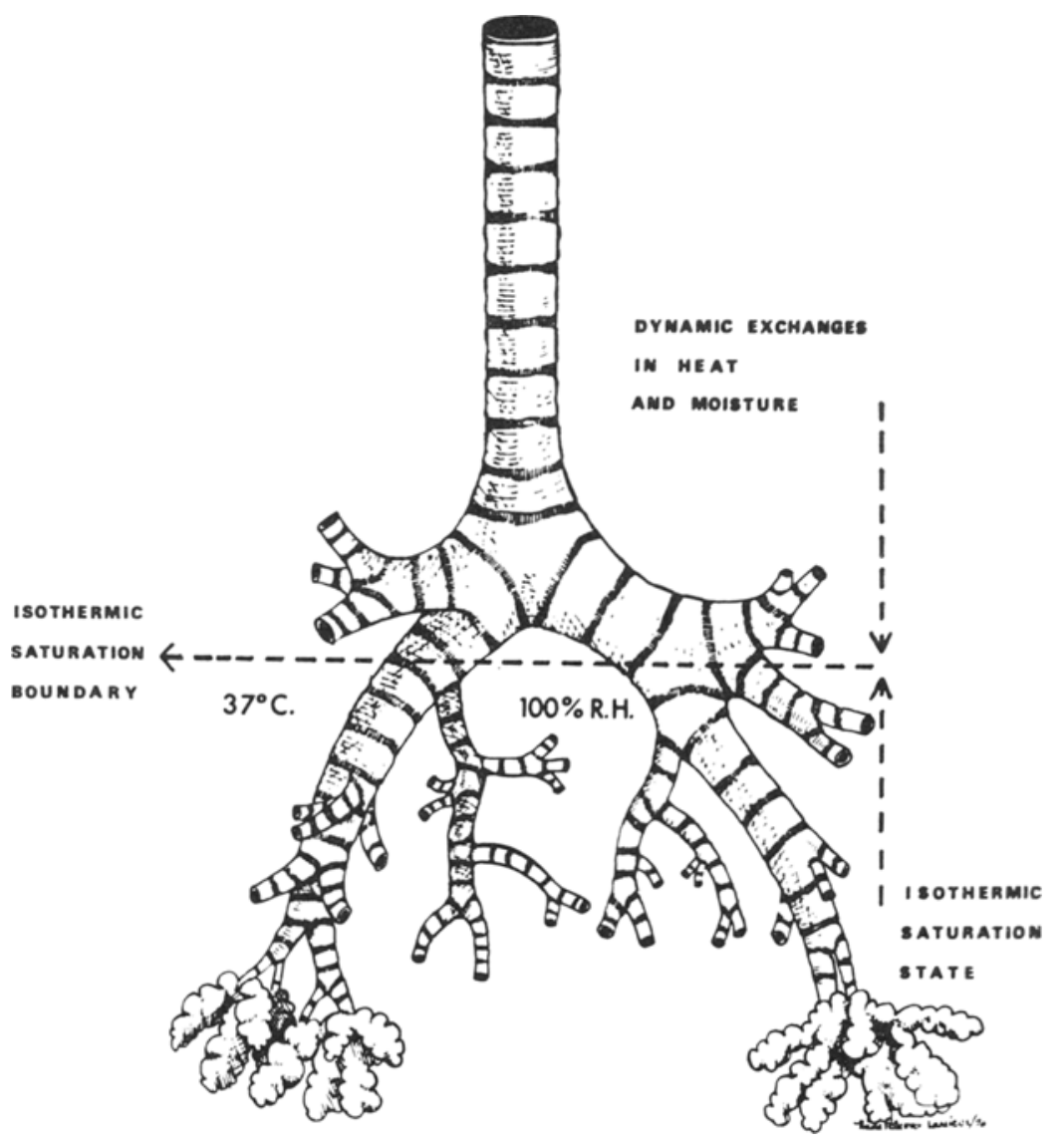

Figune 3. Conceptual view of the Isothermic Saturation Boundary.

and respiratory physiologists because its upward and downward movements have major implications in the physiology of ciliary activity, mucus production and rheology, both factors responsible for the integrity of the mucous membrane.

Our results, at this point, indicate that this isothermic saturation boundary will shift in response to two specific factors. First, the humidity and temperature of the inspired air; the drier and the cooler it is, the lower the ISB will fall. Secondly, for a given steady state of temperature and moisture at a specific site in the airway, the ISB will move with the inspired tidal volume. An increased tidal volume will result in a downward shift of this isothermic saturation point. In other words, the ISB is dependent upon both the quality and the quantity of the gas mixture being breathed. This conceptual view dealing with the heat and moisture homeostasis in the respiratory tract is tentatively illustrated in Figure 3.

The fact that the Isothermic Saturation Boundary will never fall to the respiratory membranes insures a stable $\mathrm{PH}_{2} \mathrm{O}$ not only in the functional residual capacity, but also in blood and tissues. ${ }^{18}$ 


\section{Summary and Conclusions}

During general anaesthesia in dogs ventilated with a dry gas and using a nonrebreathing system, measurements of relative humidity and temperature directly from the alveolar cavity disclosed the constant pattern of saturation at body temperature. Maximal hyperventilation did not modify this biological constant.

Two conclusions can be drawn from these studies. First, the alveolar lining, in the conditions of our experiments, seems to be well protected against cold and dehydration. Second, our results stress the magnitude of the functional capacity of the upper airway as a biophysical air conditioning system.

\section{REFERENCES}

1. Weibel, E. R. Morphometry of the human lung. New York, Academy Press, 1963.

2. Modfll. I. H.; Moya, F.; \& Rutz, F. C. Blood gas and electrolyte determination during exposure to ultrasonic nebulized aerosols. Brit. J. Anaesth. 40: 20-26 (1968).

3. Bensos. D. W.; Hurt, H. C.; Rashad, F. K.; \& Graff, T. D. Application and evaluation of humidification in anaesthesia systems. Communication given at the 40th Congress of the International Anesthesia Research Society, Bal Harbour, Florida, February 27 to Narch 3, 1966.

4. Déry. R.: Pelletier, J.; Jacques, A.; Clayet, M.; \& Houde, J. J. Humidity in Anaesthesiology: Ir. Evolution of heat and moisture in the large carbon dioxide absorbers. Canac. Anaesth. Soc. J. 14: 205-219 (1967).

5. Déry. R.: Pelletier, J.; Jacques, A.; Clavet, M.; \& Houde, J. J. Humidity in Anaesthesiology: in. Heat and moisture patterns in the respiratory tract during anaesthesia with the semi-closed system. Canad. Anaesth. Soc. J. 14: 287-298 (1967).

6. Déry, R. Humidity in Anaesthesiology: v. Evolution of heat and moisture in the tracheobronchial tree during anaesthesia with a non-rebreathing system. To be published.

7. Weeks. D. B. \& Broman, K. E. A method of quantitating humidity in the anaesthesia circuit by temperature control: The semiclosed circle. Anesth. \& Analg. 49: 292-296 $11970)$.

8. Déry. R.: Pelletier, J.; Jacques, A.; Clavet, M.; \& Houde, J. J. Humidity in Anaesthesiology: r. A modified dew-point hygrometer. Canad. Anaesth. Soc. J. 14: 104 (1967).

9. Ilorvath, S. M.; Rubin, A.; \& Foltz, E. L. Thermal gradients in vascular systems. Am. J. Phrsiol. 16I: 316-322 (1950),

10. Eichna. L. W.; Berger, A. R.; Rader, R.; \& Becker, W. H. Comparison of intracardiac and intravascular temperature with rectal temperature in man. J. Clin. Invest. 30: 353359 ( 1951$)$.

11. Mather, G. W.; Nahas, G. G.; \& Hemingway, A. Temperature changes of pulmonary blood during exposure to cold. Am. J. Physiol. 173: 390-392 (1953).

12. COLE. P. The recording of respiratory air temperatures. J. Laryngol. Otol. 68: 295-307 (1954).

13. Amistrosg, H. C.; Burton, A. C.; \& Hall, G. E. The physiological effects of breathing cold atmospheric air. J. Aviation Med. 29: 593-597 (1958).

14. Rrbeistein, E. R.; Pardee, C.; \& Eldridge, F. Alveolar capillary temperature. J. Appl. Phisiol. 15: 10 (1960).

15. Cravistox, W. I.; Gerbrandx, J; \& Sxell, E. S. Oral, rectal and oesophageal temperatures and some factors affecting them. J. Physiol. London. 126: 347-356 (1954).

16. Harris. E. A. \& Porter, B. B. On the heart rate during the exercise, the oesophageal temperature and the oxygen debt. Quart. J. Exptl. Physiol. 43: 313 (1958).

17. Stipel. M. \& Severinghaus, J. W. Internal body temperature gradients during anaesthesia and hypothermia and effect of vagotomy. J. Appl. Physiol. 9: 380-386 (1956).

18. Eristr. E. A. \& Perez-Zamora, P. Water vapor pressure in blood and tissues. Anesthesiolog, 3L: 272-274 (1969). 